\title{
Should a Christian adopt methodological naturalism?
}

\author{
Andrew B. Torrance
}

\begin{tabular}{|l|l|}
\hline Date of deposit & 26022017 \\
\hline Document version & Author's accepted manuscript \\
\hline Access rights & $\begin{array}{l}\text { C } 2017 \text { by the Joint Publication Board of Zygon. This work is } \\
\text { made available online in accordance with the publisher's policies. } \\
\text { This is the author created, accepted version manuscript following } \\
\text { peer review and may differ slightly from the final published } \\
\text { version. }\end{array}$ \\
\hline $\begin{array}{l}\text { Citation for } \\
\text { published version }\end{array}$ & $\begin{array}{l}\text { Torrance, A. B. (2017). Should a Christian adopt methodological } \\
\text { naturalism? Zygon, 52(3), 691-725 }\end{array}$ \\
\hline $\begin{array}{l}\text { Link to published } \\
\text { version }\end{array}$ & \begin{tabular}{l} 
https://doi.org/10.1111/zygo.12363 \\
\hline
\end{tabular}
\end{tabular}

Full metadata for this item is available in St Andrews Research

Repository at: https://research-repository.st-andrews.ac.uk/

\section{St Andrews Research Repository}




\section{SHOULD A CHRISTIAN EVER ADOPT METHODOLOGICAL NATURALISM?}

\section{Forthcoming in Zygon}

It is standard practice within the natural sciences for Christians to avoid making reference to God, let alone to the possibility that God is actively involved in the world. ${ }^{1}$ Natural scientists are in the business of dealing with those things that are seen. Consequently, they are obliged to pursue their research by referring exclusively to those things that can be discerned directly within the contingent order. If scientists were to observe something, therefore, that appeared to present an anomaly (water turning into wine, walking on water, bodily resurrection, or the miracles of Muhammad), they would not jump to the conclusion that "God did it". Such a conclusion would function as a "science stopper." That is, it would allow scientific investigation to give up too quickly when faced with curiosities that go against the grain of the scientific worldview that is operating. So, if a person appears to have been healed in a way that eludes medical explanation, contemporary science will not see "God answered our prayers" as a satisfactory alternative. Instead, such healing will invite further empirical, scientific investigation-investigation that could serve to benefit others with similar illnesses.

To challenge such a methodology, one would have to provide evidence of the most extraordinary kind. It would have to be such that it generated a wide consensus within the scientific community not only that God exists but that God can be recognised from within a nonChristian worldview to be actively impacting on the operations and applications of the laws of nature-laws that science assumes (and must assume) in order to function. Put simply, if the secular scientific community cannot find empirical evidence that God exists and is observably active in particular events then it could not possibly believe that it is warranted in interpreting anomalies as miracles.

Again, the natural scientist devotes her life to furthering our understanding of the behaviour and structure of the universe as it is immediately apparent to us. The scientist focuses her attention on secondary causes that can be openly observed and/or explained within the contingent order. She does not concern herself with asking questions about a first cause, or, indeed, about the possibility of a first causer acting invisibly in the physical world. Scientists Harry Lee Poe and Chelsea Rose Mytyk write: 'People may believe that God knitted them together in their mothers' wombs on the authority of Scripture. To be science, however, it is necessary to describe what that knitting looks like physically in the body' $(2007,214)$. 
Given the hiddenness of God, it has become mainstream for scientists (both theistic and non-theistic) to go a step further to avoid the possibility of reference to God. They adopt methodologies that are committed to studying the world on the following suppositions or assumptions: (1) that God does not exist-methodological atheism (hereafter MA); (2) that the reality of the universe is to be explained solely with recourse to matter with its movements and adaptations - methodological materialism; and/or (3) that the reality of the universe, as it can be accessed by empirical enquiry, is to be explained solely with recourse to natural phenomenamethodological naturalism (hereafter $\mathrm{MN}$ ). ${ }^{2}$ Although these methodologies are often used interchangeably, Christians tend to find MN more attractive than the other two. The reason for this is that $\mathrm{MN}$ can seem like an appropriate way to focus attention on natural phenomena, while bracketing out the creator of these phenomena.

There is, however, an inconsistency in this line of reasoning for MN. It presupposes a theology of nature (that there is a creator to bracket out), even though this is precisely what is ruled out by a naturalistic method. ${ }^{3}$ It is important to be clear here that $M N$ does not bracket out God; it is the Christian who brackets out her belief in God in order to adopt MN. As such, once the Christian has committed to studying the world by way of $\mathrm{MN}$, she operates with the assumption that the entire structure and behaviour of the natural physical world requires to be explained without God, without a theology of nature. ${ }^{4}$ Not only that, but by committing to a systematic methodology that discounts a recognition of God's activity from scientific practice, she assumes that her Christian beliefs would potentially obstruct her study of the natural world. ${ }^{5}$

That aside, MN can still seem to make some sense for many Christians. Why is this? It is orthodox for a Christian to believe that God is transcendent, and cannot be studied as a part of the furniture of the world - as a visible object that is "pegged out to view". This means that there are clear theological reasons for the Christian scientist to assume that her research will normally be characterised by an absence of explicit theological reference. She should recognise that God's activity should not be confused with the regular and immanent processes that characterise the natural world, and which are the subject-matter of normal scientific enquiry. If the world is not God's body and the laws of the contingent order are not to be identified with God's free agency, then the Christian should not see God as directly accessible to or the direct object of empirical, scientific study.

If this is the case, what could be wrong with endorsing a methodology that reflects the apparent absence of God? First, for many Christians, there are actual occurrences that take place within the natural order that do require to be explained with recourse to special divine action: for example, the incarnation, the miracles of Jesus, the resurrection, and Pentecost. ${ }^{6}$ It is not only past 
events, however, that may require to be explained in this way. There is biblical precedence for thinking that the very recognition of the truth of the Christian faith requires direct divine action. It is suggested that it is in and through the creative and transformative presence of God that persons are given the eyes to see and ears to hear what flesh and blood cannot discern (Matthew 16:17 NRSV). ${ }^{7}$ Still further, many Christians are committed to more general claims about the natural order that involve the recognition of God's activity: it is divine action that explains why there is anything contingent at all ("something rather than nothing"); divine action is the reason that there is order in the cosmos that is intelligible for science; and God explains the emergence of particular creatures who reflect the image of God.

If the Christian is consistently committed to $\mathrm{MN}$, however, all of the above requires to be explained without recourse to any kind of reality that does not belong to the natural order (at least while she is adopting MN). In the name of naturalistic science, no recourse can be made to a God who is hidden from scientific investigation to help us understand the natural world and its history for the simple reason that MN rules out any such reference. As Peter Harrison argues, MN is characterized by a 'commitment to study the world as if God plays no part in the secondary causes of nature' $(2010,12)$. It is hard to see why such a position would not, at least sometimes, be problematic for the Christian.

But what if the Christian scientist were only to adopt $\mathrm{MN}$ when she believed that she did not need to refer to God-for example, when she is studying the behaviour of bacteria or black holes? Under these circumstances, the supposed commitment to MN would be contained within an overarching methodological agenda that is logically incompatible with $\mathrm{MN}$. That is, $\mathrm{MN}$ would be subordinate to a more foundational Christian methodology that determines precisely when and where it is appropriate or inappropriate to bracket God out of the equation. In short, it is hard to see how such a person would be consistently committed to MN. It might be strategically wise for Christians to make such a claim within the academic context, but it is hard to see how it is warranted.

Yet, another very understandable reason for endorsing $\mathrm{MN}$ is to distance science from those within the Intelligent Design movement who refer to God in ways that can undermine scientific progress - by being too casual about "stopping science" with the explanation "God did $\mathrm{x}$ ". It is imperative that we realise here that MN and ID are false alternatives. The Christian scientist is not faced with an either/or choice between the two. She could advocate a theologically humble approach. So, for example, if a fellow Christian scientist were to make haphazard references to special divine action, ${ }^{8}$ she could suggest that, for the purposes of their particular research program, they should assume that they are unable to discern such action because, if it is 
taking place, it is not discernible by empirical study. Such an approach restricts explicit claims to special divine agency, but without disregarding the existence and action of God: it is characterized by a theological appreciation of human limitations rather than the exclusion of an agency beyond nature. In this way, there is no problem with the Christian continuing to embrace her belief in God while participating in the scientific task - there would be no need to commit to MN. There are also benefits. Belief in divine agency can give her a confidence in the order and regularity of the world - it is not simply assumed but affirmed. It can help her to appreciate that there is such a thing as objective truth, logic, and reason. And it can allow her to recognize, when faith requires, that certain occurrences and arrangements are the result of free divine action.

In this essay, I argue that the Christian should recognize that her faith in God gives her a deeper, fuller, and more accurate understanding of the history, structure, and behaviour of the natural world - by providing, not least, a wider and more integrated "compass" for the process of interpretation. As such, the work of the Christian scientist qua scientist should always recognise 'the world to be God's creation... the work of God's hands and the expression of God's delight' (Wirzba 2016, 217). A failure to do so would be symptomatic of a failure to view science as a vocation that can be Christian vocation. Further, it would express a failure to recognize the ultimate truth of the Christian faith and/or a failure to be consistent in one's commitment to the truth.

If the Christian is to resist MN, she will need to accept that there will be times when there will be a tension between her understanding and the naturalist's understanding of the natural world. When this happens, however, it is inconsistent for the Christian to try to fix this tension by conforming to naturalistic criteria. Rather, she should follow Einstein's principle: "The right to search for truth implies also a duty; one must not conceal any part of what one has recognized to be true". ${ }^{9}$ So, for example, were a Christian scientist to observe the resurrection of Jesus Christ (assuming that it is a mind-independent event that has taken place in the natural world through special divine action), the Christian qua scientist would need to be willing to allow her belief in the possibility of theological explanation to inform her scientific assessment of this occurrence. For the Christian to try to explain such an occurrence, without reference to God, would not only be unchristian, it would also (for her) be unscientific — at least according to Einstein's principle.

This is definitely not to suggest that, were a Christian scientist to observe someone rising from the dead today, she should jump to the conclusion that "God did it". In such a situation, the Christian scientist ought to seek to make sense of such an event in natural terms (again, for both theological and scientific reasons). The exception of this would be if, in some extraordinary way, God were to make it clear to the ecumenical Church that this was indeed a miracle. 
What is important to note, however, is the fact that for a Christian scientist to countenance the possibility that God's activity may ever explain an occurrence is incompatible with the commitment to adopt MN. To reiterate, this is not to suggest that the Christian's faith is likely to have a decisive impact on her scientific research. Rather, it is simply to recognise that, if she deems it possible that in any field of enquiry God could have an explanatory significance, then that recognition is inconsistent with $\mathrm{MN}$.

As will become clear, part of the appeal of MN reposes in a confusion as to why God does not feature in scientific enquiry. Divine hiddenness may be one valid reason but another is, quite simply, the focused nature of scientific work. To select a field of scientific research in which one's analysis and experimentation will take place will inevitably involve censoring or selecting out of consideration areas of enquiry that do not bear specifically on the precise operations one is studying. So, for example, neuroscience, marine biology, and political science are unlikely to shed light on cardiothoracic research so one will select out of the focus of one's enquiry results of work done in these other fields. But no scientist would dream of suggesting that one should therefore adopt a methodology that assumes that none of these disciplines have any bearing on the larger picture of the world within which one's particular form of science operates.

When it comes to the scientific study of the behaviour, structure and history of the natural world, the Christian scientist should be unwilling to interpret it otherwise than from her Christian perspective. This is definitely not to set a precedent that would invite an anything-goes relativism, whereby any religious or secular belief is given a place at the table. It is simply to recognize that the methodology of a practicing Christian should not and, indeed, cannot be divorced from what she believes she knows and the fundamental ontological claims that this involves.

To try to make this case in a comprehensive manner, I shall now offer a critical examination of the positions of some of those who encourage Christians to embrace MN. I shall then go on to look at some of the problems that can arise from a commitment to MN. Finally, I shall conclude that the Christian scientist should not commit to a methodology that makes assumptions that are incompatible with her Christian assumptions. Instead, the Christian scientist qua scientist should seek to study the natural world as a Christian studying creation.

\section{CHRISTIAN VIEWS OF METHODOLOGICAL NATURALISM}

As Christians who are committed to $\mathrm{MN}$ are quick to point out, $\mathrm{MN}$ only insists on naturalism for the purpose of 'disciplinary method' (De Vries 1985, 389). ${ }^{14}$ In this respect, it is to be distinguished from metaphysical naturalism, which insists on naturalism tout court — not only for 
methodological purposes. It is because the Christian who adopts MN or MA only assumes a closed world for the purposes of method that it has become commonplace for many Christians to view it as an appropriate methodology for the sciences as well as for many other areas of scholarship. However, as I shall suggest, it is not as easy to sustain a sharp distinction between MN and metaphysical naturalism as is sometimes suggested, especially for the person who finds herself operating within a domain that is defined by a commitment to MN. To argue this point, it will be helpful to consider the views of some of the many Christian thinkers who endorse MN or MA for the purpose of the natural sciences.

Paul De Vries contends that Christians should be 'enthusiastic supporters of the naturalistic methodology of the natural sciences' $(1985,394)$. Nancey Murphy asserts that we should embrace an approach to the natural sciences that is 'methodologically atheistic' and then adds, 'Christians and atheists alike must pursue scientific questions in our era without invoking a creator' (1993, 33-34). More recently, Ronald Osborn has argued that MA is necessary not only to protect science from religion but to protect theology from diminishment, trivialization and manipulation by scientists. In a chapter entitled, 'Does Your God Need Stage Props?: On the Theological Necessity of Methodological Atheism', he writes:

The move to exclude "natural theology" from science was first championed not by Darwin but by Isaac Newton and Robert Boyle, who saw that the metaphysical mixing of modern empirical methods with religious teleology resulted not only in bad science but also in a corruption of true faith. God's transcendence theologically requires a radical distinction between God as Creator and the operations of the universe through secondary causes that can be empirically observed and tested through inductive and deductive methods. $(2014,16)$.

When one analyses the various accounts of $\mathrm{MN}$, what quickly becomes clear is that there is a whole range of interpretations of MN and what precisely it implies. Some scholars, like Osborn and Murphy, identify MN with MA. Whereas others want to align MN with a Christian understanding of the world.

What is clear is that many of the concerns that drive Christians to adopt MN are justifiable. There are very good reasons to exclude natural theology from the sciences. Also, as I have suggested, it belongs to Christian orthodoxy to affirm that neither God nor God's activity should be seen to be an object of scientific observation, speculation, and experimentation. 
This leads us to consider the positions advanced by advocates of MN who seek to offer a more theologically sensitive approach.

\section{CAN NATURALISTIC SCIENCE PERMIT NONSCIENTIFIC APPEAL TO THE DIVINE?}

According to Robert O'Connor, MN 'must refer to wholly natural phenomena, making no reference to immediate or direct contribution by nonnatural or supernatural agency'. He then adds, however, that scientific accounts can permit 'further, nonscientific appeal to the divine as the ultimate and sustaining source, meaning, and purpose of all natural phenomena' (1997, 16). He writes:

\footnotetext{
The goal of natural $^{15}$ science should be conceived as aiming toward an understanding of natural entities, processes, events, states of affairs, relationships, and such, as natural entities, processes, events, states of affairs, relationships, and such, i.e., explaining those phenomena from start to finish in natural terms. This does not commit the scientist to the view that all phenomena can be given a complete natural explanation (or indeed any), but only to the view that scientific explanations account for natural phenomena as far as they can in completely natural terms. $(1997,17)$.
}

What O'Connor is proposing is a conditionalising approach whereby the scientist determines to operate within a within a circumscribed domain, assuming that scientific explanation within that domain proceeds in 'completely natural terms' $(1997,17)$.

O'Connor's account of MN is about as theologically sensitive as it is possible to be. He presents $\mathrm{MN}$ as a methodology that serves to interpret the natural order in its own terms, within a circumscribable field. MN is the method of natural science, and God is not an object of natural science. Yet, there seems to be an inconsistency or, at least, lack of clarity in his account. This raises the question: is he more theologically sensitive than a standard account of MN would allow him to be? He suggests that scientific accounts, characterized by $\mathrm{MN}$, can be understood as permitting 'further, nonscientific appeal to the divine as the ultimate and sustaining source, meaning, and purpose of all natural phenomena' $(1997,16)$.

To be clear, $\mathrm{MN}$ is an approach to science that develops scientific accounts that are essentially naturalistic, insofar as they have been developed by MN. To the extent that a scientific 
account is naturalistic, it cannot permit any appeal or reference to the reality of God. It is only the scientist qua theist (who is not adopting MN) who can make non-scientific appeal to God by moving from the domain of her scientific understanding to the domain of her theological understanding. However, since her scientific account would be naturalistic and her theological account would be theological, the two would be incompatible with one another. What the scientist can do, as O'Connor suggests, is reinterpret her scientific account within a theological framework. However, if she does this, she essentially changes the nature of her scientific account - it is no longer naturalistic.

It is hard to work out why O'Connor is committed to MN. Just because a scientist's attention is focusing on a domain where neither God nor God's activity can be directly known does not mean that her methodology needs to be naturalistic. Denis Alexander writes: 'We don't call Christian accountants "naturalistic" because of the absence of theological terminology as they check the company accounts, any more than we expect our doctor to use theological language when she tells us that we've got the flu, or the mechanic to refer to biblical texts when servicing our car. The absence of specific references to God does not render our lives suddenly "naturalistic"” (2008, 186).

In short, the MNist (person who is committed to MN) does not simply discount God or avoid referring to God. While a scientist is adopting $\mathrm{MN}$, she is unable to recognise that there is a God to discount. Rather, it is the theist, who is adopting MN, who is obliged to discount God. It would therefore be more consistent for the Christian to adopt a methodology that acknowledges the hiddenness of God rather than a naturalism that rules out the possibility of recognising that God has anything to do with the natural order.

\section{IS MN AN APPROPRIATE MEANS OF HONOURING GOD'S WORK IN CREATION?}

Kathryn Applegate offers a similar defense of MN to that of O'Connor. However, she also has some additional things to say that are worth considering. So, I am going to devote four subsections to Applegate's defense. The reason for this is that the various aspects of her position accurately represent some of the key reasons why so many Christian thinkers think that $\mathrm{MN}$ is a viable option.

For Applegate, $\mathrm{MN}$ is 'the scientific practice of limiting the explanation of natural phenomena to only natural mechanisms'. She continues: $\mathrm{MN}$ 'was originally upheld by philosophers and scientists who sought to honor God by discovering his work in creation and by not invoking him in place of secondary causes' $(2013,37) .{ }^{17}$ As such, MN demonstrates a deep 
respect for the creator/creature distinction by ensuring that God's activity is not confused with creation's activity. ${ }^{18}$

This seems somewhat counterintuitive since MN does not allow the Christian scientist qua scientist to discover God's work in creation as such. MN merely develops a naturalistic account of phenomena in the natural world. Now, again, it is possible for the Christian scientist qua Christian to revert to a theological method to reinterpret these scientific accounts theologically. $\mathrm{MN}$, however, does not allow for such reinterpretation. However, as I've been arguing, the Christian should not need to compartmentalize her theological and scientific worldview. She does not need to adopt $\mathrm{MN}$ in order to avoid invoking God in place of secondary causes. A theological method can serve that end with clarity, consistency, and, indeed, coherence.

Applegate appears to defend a kind of localized MN which allows the scientist to continue to operate with a theology of nature. ${ }^{19}$ This begs the question as to why the Christian scientist cannot operate with one overarching Christian methodology which, for consistent reasons, limits the extent to which a person can refer to God in her scientific studies. Such an approach could allow the scientist to refer to God when her faith requires this of her but refrain from doing so when it is not warranted.

To be clear, Applegate is emphatic that scientific activity is not in tension with the Christian faith. She acknowledges that ' $[\mathrm{w}]$ hatever process one studies, from the birth of stars to intracellular dynamics, it does not explain away God's activity in the world' (2013, 37). Her concern is to affirm, rightly, that the scientist observes realities that do not directly reveal the existence of God, because God transcends the natural order. Here, her position here aligns with T.F. Torrance's adoption of a "methodological secularism". He writes:

...the acceptance of the contingent, autonomous nature of the world called for the development of autonomous modes of scientific inquiry appropriate to it. This involved what might be called a "methodological secularism", i.e., an orientation in which science bracketed the world off from its relation to God, in order to investigate its nature for its own sake. That was certainly in line with the renewed stress of the Reformation upon God's creation of the world out of nothing, and of the primacy of his grace in which God turns toward the world he has made, which summons man to join him in that movement of his grace toward the world, and that had the effect of making natural scientific investigation of the world part of man's obedience to the Creator. $(1998,41)$. 
On a similar note, Conor Cunningham asserts that $\mathrm{MN}$ 'is the approach that science must take when it engages with the universe insofar as it will fail to make any progress unless it brackets out the divine... [So, a] certain methodological naturalism is commonsensical' (2010, 265-66).

Torrance's and Cunningham's description of MN is deceptive. It is not science that brackets off God, but theists who decide to bracket off their belief in God in order to practice science naturalistically (or secularly). ${ }^{20}$ When $\mathrm{MN}$ is adopted, all scientific explanations are limited to naturalistic explanations. So, by adopting $\mathrm{MN}$, the Christian decides that a naturalistic understanding is more appropriate to the scientific task than her theistic or Christian understanding. This, however, raises the question of criteria. It is commonplace to recognize that the criteria a person decides to adopt in scientific research are not themselves determined by thought processes that are inherently scientific. Rather, this decision is based on metaphysical assumptions about the nature of reality and, more specifically, about what that person considers to be the most appropriate assumptions to inform scientific method.

To return to Applegate's earlier point, it is quite right to suggest that belief in the existence of a creator can help the scientist to go about her task in the way that she does, trusting in the order of the universe. However, if this is the case, why would a Christian not allow her theological assumptions to inform her methodological assumptions-even if these theological assumptions make no external difference to her scientific practice? At the very least, would it not make more sense for a Christian scientist to adopt a methodological deism? This would at least mean that her method would not require her, in her capacity as a scientist, to rule out recognition of the existence of God.

\section{IS IT EVER APPROPRIATE FOR SCIENCE TO DISREGARD ANOMALIES BECAUSE THEY DO NOT CONFORM TO STANDARD SCIENTIFIC METHOD?}

The defining tension at the heart of Christian MNism is reflected in Applegate's comment that 'the Bible reveals a God who normally accomplishes his purposes through means such as natural processes or human activity' $(2013,38)$. The same problem is apparent in John Hare's comment that 'Methodological naturalism is reasonable for most of science, since we cannot put God in the lab' $(2012,247)$. What this indicates is that Christian MNism can run into problems. The Christian MNist is committed to a methodology that does not allow for the possibility of key events within the contingent order that they recognize have profound significance: i.e. every single event that requires to be identified with God's active involvement in human history. 
Why would this be a problem? For most scientists, a methodology that rules out the possibility of providing an adequate account of certain occurrences (within the natural order) would not be considered an adequate methodology. A scientific approach should allow anomalies (that cannot be explained away) to challenge and thereby revise their interpretative models and methodology. Science cannot ignore or rule out anomalies simply because they do not fit with standard scientific practice. Of course, for metaphysical naturalists, $\mathrm{MN}$ does not constitute a problem, since they rule out a priori any involvement of God in any facet or reality. Many Christians, however, do claim that reference to God is required to make sense of certain occurrences within the natural order. So, under certain circumstances, many Christians will recognize that $\mathrm{MN}$ will undermine their interpretation of natural history.

To account for this, Applegate notes that science cannot 'capture all of reality, including the possibility of God's direct action in natural history' and considers miracles to be 'the blind spot of science' $(2013,41)$. The trouble with MN, however, is that it does not allow the Christian scientist to recognize miracles as blind spots. MN requires the Christian scientist to offer naturalistic explanations of these spots that are likely to be inconsistent with her Christian understanding. Therefore, the Christian would again need to operate with an overarching methodology with which she could determine what counts as a blind spot, and thereby avoid adopting MN when it would undermine her Christian understanding. If she were to do this, however, her scientific study would not consistently be characterized by MN. Rather, it would be characterized by a methodology that sometimes required her to employ to naturalistic criteria (e.g., when she believed that a Christian scientist was making inappropriate references to God) and, at other times, required her to employ non-naturalistic criteria (e.g., when she believed that a miracle had genuinely taken place).

If this is the case, it is hard to see why Applegate should not advocate a scientific methodology that consistently corresponds to her Christian perception - a methodology that would not require her to mis-explain the blind spots. Again, this would not mean that her interpretation of the natural order would need to appear any different from the naturalist for the majority of the time, that is, unless her Christian understanding requires this of her.

\section{AM I CONFUSING MN WITH METAPHYSCIAL NATURALISM?}

One way that Applegate and others might respond is to say that this is to confuse MN with metaphysical naturalism. I have already acknowledged that I think that there is a difference between the two. At the same time, however, I do not think it is as easy to draw a line between 
the two of them as is often suggested. For instance, if a scientist is consistently adopting MN, there will be no difference between her explanations and those of the metaphysical naturalist. The only difference between the two is that the MNist may be committed to different metaphysical assumptions that she chooses to set aside in order to adopt $\mathrm{MN}$ and which determined when MN should and should not apply.

It is widely assumed that $\mathrm{MN}$ is metaphysically neutral because it is only concerned with the scientific practice of interpreting natural phenomena. But this is just not the case. The person who adopts $\mathrm{MN}$ assumes that naturalism is the most appropriate philosophy for systematizing scientific investigation. And that is not a metaphysically neutral assumption (McMullin 1982, 328; see also Gregory Dawes 2011). When a person advocates a particular methodology for approaching a particular object, she will normally do so because she has metaphysical views about the nature of that particular object: about how that object relates to reality, and about the nature of the reality within which that object finds itself. For example, a scholar of literature is likely to have metaphysical reasons for not adopting methodological materialism to interpret Dostoevsky. She believes, for example, that The Brothers Karamazov has inherent qualities that transcend the materiality that makes up the pages of the book. Therefore, she is likely to believe that these inherent qualities make this book more valuable than a block of wood-even though a block of wood will be more effective at fueling a fire. To believe this is normally to acknowledge that there is more to reality than the purely material. As such, she has metaphysically informed reasons for thinking that it is inappropriate to interpret this book by adopting methodological materialism.

Similarly, it would seem that there should be metaphysical reasons for the Christian scientist not to interpret the natural order with MN. The Christian believes that the natural world has order, is contingent, and is created and maintained by a God who acts in its history in special ways. As I have been arguing, the Christian scientist qua scientist should continue to be mindful of her Christian commitments. She should engage in the natural sciences with a humble awareness that God is (normally) hidden rather than with the assumption that God has nothing to do with the natural order. With this approach, the Christian can view science as a Christian vocation and can assume that her faithful understanding and her scientific practice are wholly compatible with one another-she can engage with the world with an integrity of understanding. And when, for example, a scientific theory is advanced that is essentially incompatible with her Christian faith, because of it naturalistic assumptions, that same intellectual integrity will lead her to call this theory into question.

On the other side, I would also argue that it is possible for certain scientific discoveries to make a difference to a person's Christian beliefs (for example, how she interprets the Genesis 
creation sagas). If the Christian believes that her Christian beliefs correspond to the reality of the natural world, then the Christian should not feel a need to commit to bracketing out some of her Christian beliefs in order to practice science. As Tom McLeish writes: 'a theological tradition is all-encompassing. In Judaism and Christianity the universe itself carries theological weight as God's creation, it carries rational weight as our human environment - with both positive and painful consequences. Keeping science and theology at arm's length artificially limits their domains of discussion - and this is inconsistent with the range of both of them.' $(2014,168)$.

To return to Applegate, it is hard to work out where the nodal point lies which obliges her to take a different turn and therefore to reject this approach. Indeed, towards the end of her article, she refers to Denis Alexander as someone who thinks that Christians should drop the term MN and talk more generally about scientific explanations. ${ }^{21}$ For Alexander, there are good theological reasons for seeking to ensure 'that the scientist does not invoke God as an explanation for things in the course of his or her daily scientific research' $(2008,186)$. But, for him, the Christian does not need to take up $\mathrm{MN}$ to do this, and he is rightly concerned that $\mathrm{MN}$ comes with 'the unstated implication...that the Christian will somehow leave their faith in God behind the laboratory door' (2008, 186). Reflecting on his own scientific practice, Alexander writes: 'When I walk into my laboratory I do not suddenly stop believing in God - far from it, I go in as the Christian explorer looking forward to uncovering more of the wonders of God's world. The more we discover, the more we glorify God by revealing his thoughts in the created order...Naturalism is the philosophy that there is no God in the first place, so only an atheist can provide truly naturalistic explanations for anything.' (2008, 185-86).

Although Applegate considers Alexander's suggestion that we drop the term $\mathrm{MN}$ as 'wise counsel indeed' $(2013,41)$, she goes on to argue: 'surprisingly, methodological naturalism frees us to envision God... as faithfully and lovingly preserving, redeeming, and remaking all things in Christ. Methodological naturalism, when practiced by a Christian, presupposes the sovereignty and consistent sustaining work of God' $(2013,42)$. What becomes clear here is that Applegate is defending a version of $\mathrm{MN}$ that can be adopted with Christian presuppositions. If this is the case, the question arises as to why Christians would want to claim the term 'naturalism' for themselves, given that, in the contemporary world, it is normally equated with atheism. Not only would this invite confusion, but, if Christians were to do this, they would find that non-Christians were operating with a very different version of $\mathrm{MN}$ — one that denies the existence of anything beyond the natural order. This would be to suggest fundamental agreement where there is none.

To conclude this section, my argument is quite simple. The Christian should consistently seek to interpret the nature of reality by making use of all that she knows. At the very core of the 
Christian faith, is the claim that God not only exists but that God brought this contingent order into existence as an intelligible reality. Furthermore, the Christian believes that God is actively involved in history, creating a faith that can serve as a witness to God's creative, providential, and redemptive activity. For this reason, there should be a difference between the way in which the Christian and the naturalist approach and interpret the structure, behaviour, and history of the natural world.

\section{THE THREAT OF METHODOLOGICAL NATURALISM}

Since MN receives so much support from Christian thinkers, it might be helpful to consider ways in which $\mathrm{MN}$ can become a problem for some Christians in practice.

To be clear, the argument of this essay is not contingent upon its dismissal of MN making a visible difference to the specific area of person's scientific research. However, if it does not make such a difference whether a Christian's methodological assumptions are seen to be naturalistic or Christian (assuming there is, at least, some difference between a naturalistic and a Christian understanding), then this raises the question as to why the Christian should feel a need to commit to MN. Why could she not simply get on with the practice of science in a way that does not bracket out her Christian outlook on life? If so, she could openly recognise that there is a compatibility with her Christian commitments and her scientific practice, without qualification?

In this section, I propose that there are three particular problems that $\mathrm{MN}$ causes for Christianity: (1) it encourages scientists to develop theories that are essentially incompatible with Christianity; (2) it creates or underpins a culture that perceives there to be a tension between science and Christianity; and (3) it can prompt Christians to disregard the reality of God or, at least, perceive the reality of God as something that should not be taken seriously in certain domains of intellectual discourse.

\section{(1) MN ENCOURAGES SCIENTISTS TO DEVELOP THEORIES THAT ARE ESSENTIALLY INCOMPATIBLE WITH CHRISTIANITY.}

One of the most apparent ways in which MN poses a threat to Christianity is when it invites scientific theories that, due to their naturalistic assumptions, end up being incompatible with theism. This point has been discussed in more detail by Alvin Plantinga who, alongside Michael Rea, offers one of the foremost critiques of MN (Plantinga 1996; Rea 2002, 62-65). I do not wish to devote too much space to reiterating Plantinga's arguments. However, it is worth mentioning 
his main point and commenting on it briefly.

In his essay, 'The Games Scientists Play', Plantinga provides some examples of theories that assume that God does not exist, even though such theories could easily be developed in a way that allow for the possibility that God exists. In particular, he looks at the theory of religion that is advanced by sociologist Rodney Stark. In Stark's theory, religion is presented as an imaginary construction of rational thought that arose over time, as human beings sought to realize the possibility of acquiring 'non-existent goods - eternal life, a right relationship with God, salvation, remission of sins-by negotiating with non-existent supernatural beings' (Plantinga 2009, 140). In short, Stark's view is that, through the process of evolution, human thought came to be characterized by a tendency to dream up fantasies which delude them into thinking that nonexistent goals are real. This is what led to the development of religion. So, for example, in times of desperation, when there seemed to be no natural options, communities would take up the view that offering a sacrifice to a supernatural being might help to bring about a change in the state of affairs. For Stark, as Plantinga interprets him, religion 'is devoted to the pursuit of non-existent goods by way of negotiation with non-existent supernatural agents' $(2009,141)$.

Plantinga notes that 'taken neat', Stark's position 'is clearly incompatible with Christian belief, according to which at least some of the supernatural beings and some of the goods mentioned do indeed exist' $(2009,141)$. However, he suggests that it would be possible to alter Stark's theory in a way that does not stop it from being scientific, but enables it to be noncommittal on the question as to whether or not a supernatural agent exists. Such a theory could be compatible with Christianity. Plantinga refers to this alternative as 'Stark minus'. On this account, rather than referring to supernatural beings as "non-existent", Stark could refer to them as "alleged". By so doing, it would take a more neutral stance to the question of whether or not God exists - a stance that seems much more appropriate to the scientific task. ${ }^{22}$ What Plantinga demonstrates in this example is a way in which $\mathrm{MN}$ can bias science (or sociology) in a way that needlessly makes a theory incompatible with theism, when there is no scientific reason for doing so.

By turning to $\mathrm{MN}$ to ensure that no reference to God is made in a scientific investigation, the Christian invites theories that are incompatible with Christianity because of their naturalistic assumptions. The critical point here is that $M N$ does not itself rule out the possibility of developing theories that are informed by metaphysical assumptions, it merely restricts a person from making non-naturalistic assumptions. In order to avoid drawing naturalistic conclusions, a person would require non-naturalistic criteria with which she could judge when it was inappropriate to draw naturalistic conclusions. Obviously, MN cannot steer a person away from drawing inappropriate 
naturalistic conclusions because $\mathrm{MN}$ assumes naturalistic criteria. Therefore, there would be no reason for the MNist to think that it would be an overstep to conclude that God is merely a product 'of the supernatural imagination'. ${ }^{23}$

Another point to make here is that the only reason to prescribe MN would be to avoid reference to God when some theists might think that it would be okay to do so. Generally speaking, even those in the Intelligent Design movement will not refer to God, for example, when making observations about chemical reactions, material composition, physical movement etc. It is only when speculating about underlying causes, which might leave room for a more metaphysical form of reasoning, that scientists will propose employing MN. Under these circumstances, the scientist does not avoid the possibility of metaphysical reasoning, she merely restricts metaphysical reasoning to naturalistic reasoning. Bradley Monton writes:

If science really is permanently committed to methodological naturalism-the philosophical position that restricts all explanations in science to naturalistic explanations - it follows that the aim of science is not generating true theories. Instead, the aim of science would be something like: generating the best theories that can be formulated subject to the restriction that the theories are naturalistic. More and more evidence could come in suggesting that a supernatural being exists, but scientific theories wouldn't be allowed to acknowledge that possibility. (2009, $58)$.

The prospect of inviting naturalistic theories that are incompatible with Christianity is a clear reason why the Christian should discourage a commitment to $\mathrm{MN}$, lest she find herself committed to practicing science in a way that may require her to be disingenuous in her assessment of natural history. It is hardly rational for the Christian (or, indeed, any other kind of theist) to employ a method that requires her to amputate the legs on which she stands so that she can be accommodated by the procrustean bed that is naturalism. And that is the case even if such a sacrifice would never actually require her to develop theories that conflicted with Christianity.

\section{(2) MN CREATES A CULTURE THAT AFFIRMS A TENSION BETWEEN SCIENCE AND CHRISTIANITY.}

When $\mathrm{MN}$ is viewed as the scholarly way to interpret reality, the academy places naturalism on a pedestal. Under its shadow, the Christian scholar finds himself under immense pressure to play 
the games of his naturalist peers in order to gain their respect and survive in the academy. ${ }^{24}$ If the Christian caves in and adopts a naturalistic methodology, he participates in a culture that takes offense at the Christian faith. This participation may only be fleeting, and it may only colour a part of his scholarship. Nonetheless, such participation expresses a sense of insecurity about the Christian faith's ability to be a witness to reality. As I have suggested, a person's decision to take up a particular methodology is not a metaphysically neutral decision. It is based on a person's understanding of what he considers to be the most appropriate methodology for understanding the particular object of his study. Therefore, if a Christian thinks that naturalism is the best metaphysic to shape scientific methodology, he assumes that there is an essential conflict between science and Christianity.

If the Christian believes that science and Christianity are compatible and yet still feels a need to adopt $\mathrm{MN}$, then he is playing the games of the secular world. He surrenders to the prevailing assumption that naturalism is more appropriate than Christianity for shaping our scientific knowledge of the natural world. What makes this all the more problematic is that human beings are, by nature, creatures that are subject to habituation. So, what we find is that methodological assumptions have a tendency to shape metaphysical perception-even if this is not necessarily the case. ${ }^{25}$ As we know from the rise of scientism, it is incredibly easy for a person's practices to become what he preaches. Therefore, a cultural perception that $\mathrm{MN}$ is the most appropriate methodology for the natural sciences encourage society to drift towards a more naturalistic understanding of reality, towards metaphysical naturalism. So, when Christians adopt methodologies that require them to bracket out their Christian commitments, they not only permit but encourage naturalism to take a hold on society. Also, when this bracketing out is done in the name of academic scholarship, the Christian furthers the perception that Christianity does not deserve the same academic standing as naturalism. By so doing, he disavows the Church, as the body of witnesses who live their lives before the triune God, the one whom Christians believe to be "the Truth."

In sum, when the Christian does not allow his methodology to conform to his metaphysic, he contributes to a culture, to the habitual mindset of a society, that is disenchanted - that is profane. Bitten by the frost of secularism, the Christian MNist becomes caught up in the trend of reducing the totality of reality to "natural phenomena." Within an academic culture that is shaped by $\mathrm{MN}$, the Christian now finds himself in a defensive position in which apologetics becomes the preferred means by which to demonstrate the intellectual viability of Christianity to a secular hermeneutic.

If he resorts to apologia, the Christian may also find that he is tempted to play down any 
beliefs perceived to be offensive to secular society. He may start to contemplate ways in which he can translate the Gospel message into secular language - into a language that masks Scripture's appointment as a witness and servant to God's self-communication. If he does this, he ceases to be a luminary, inspired by the content of his faith, and gives over his identity to the principalities and powers of secularism. This is particularly apparent when, in the culture of $\mathrm{MN}$, the Christian decides to accept Stephen Jay Gould's view of non-overlapping magisteria: that is, when he dissociates Christianity with the "hard facts" of reality and seeks to justify Christianity to the secular world by reducing it to a subjective worldview that can provide us with a sense of value and meaning. Why might this be problematic? Richard Dawkins provides an answer:

\begin{abstract}
Whatever else they may say, those scientists who subscribe to the "separate magisteria" school of thought should concede that the universe with a supernaturally intelligent creator is a very different kind of universe from one without. The difference between the two hypothetical universes could hardly be more fundamental in principle, even if it is not easy to test in practice. And it undermines the dictum that science must be completely silent about religion's central existence claim. The presence or absence of a creative super-intelligence is unequivocally a scientific question, even if not in practice — or not yet - a decided one. $(2006,82)$.
\end{abstract}

Dawkins' claims are perceptive. The existence of a purposeful creator who, at times, performs special acts within the history of creation makes all the difference to how we understand the universe. However, the Christian who acknowledges this would arrive at a very different conclusion from Dawkins. As I am arguing, the Christian should conclude that this means he should not silence his faith when it comes to scientific practice.

For the Christian, there may come a day when there is universal recognition that God exists-conceived as a mind-independent, non-natural personal agent, who is able to act in the world, and whose actions cannot be reduced to the natural operations of the contingent order. On that day, it would be hard to imagine that the scientific world would continue to believe that scientists qua scientists should discount the possibility of there being theological explanations for natural phenomena. On that day, the question on the lips of every scientist would not be, "What is to be gained by dropping the commitment to MN?" With God's universal revelation bringing about the demise of naturalism, this question would cease to be the default question in the world of science. Rather, the question that would be asked would be, "What is there to be gained by 
adopting MN?" (see Koperski 2008, 440). It is this latter question that the Christian scientist should be asking himself today. ${ }^{26}$

Before turning to consider the third problem that $\mathrm{MN}$ raises for Christianity, I shall take a moment to consider two theologies that arise in the midst of a culture shaped by MN.

\section{A. THEOLOGY OF WONDER}

An approach that Christians will often adopt to help naturalists recognize that there may be a place for God is to associate God with the wonder of the universe. To do this, they will often stress that there are some mysteries that the natural sciences are unable to explain. By pointing these out, the hope is that these mysteries might help naturalists to loosen their grip on naturalism and become more open to a constructive conversation about science and faith. To help this happen, the theist is likely to seek to inspire wonder by pointing to three things in particular: (1) the apparent existence of natural order; (2) the apparent existence of moral order; and (3) the fact that anything contingent exists or, in its more popular (and less cogent) form, that there is "something rather than nothing." 27 These mysteries have prompted extensive discussion and debate, which space does not allow us to discuss here. However, it is worth mentioning that these mysteries are often discussed within the field of science and religion so as to invite a wonder that can then, in turn, help Christians to make the case that there are reasons to believe that the universe may have been purposefully created by a necessary agent - an agent who transcends that which can be perceived by the scientist who assumes naturalism.

This approach can serve a worthwhile apologetic purpose by helping to open the minds of those who assume that it is irrational to believe in God. ${ }^{28}$ If, however, the wonder that these mysteries inspire becomes a cornerstone for theology, as it often does, ${ }^{29}$ this could be seen to raise problems. If this happens, God can come to be understood primarily as a useful explanatory postulate: the reason that there is order; the reason that there is life; the reason that we can talk about a moral reality; and the reason that there is anything contingent at all. With this theology, God comes to be viewed generically, as the mysterious one who lies beyond the limits of a closed universe that scientists can interpret naturalistically, as if there were no God. Such a position is favoured by those theists who wish to avoid stepping on the toes of those who adopt naturalism for the simple reason that the god of their theology is a deistic or Epicurean god who keeps his distance from and avoids acting in the natural order. This God created the world to be a selfsufficient world that could exist and evolve in a self-contained manner in accordance with its originally given order. 
If this theology is neither adjusted nor developed it does not present God in a way that resembles the triune God to whom the Bible bears witness. The perceived problem with the Christian idea of God, within a culture of naturalism, is that this God is personally and actively involved with the history of the contingent order. The Christian idea of God, therefore, would interfere inconveniently with the neat naturalistic criteria that the MNist employs to interpret the natural world. And this inconvenience can make it awkward for the Christian (who seeks to be taken seriously by the MNist) to advocate the God of special revelation. For this reason, the conversation about (naturalistic) science and religion rarely presents God as a God who acts within the natural order. Instead, this conversation tends to be characterized by a safe theology of wonder that constrains itself in order to seek respect within a culture shaped by a commitment to MN. ${ }^{30}$ The problem with such theology is described by Dietrich Bonhoeffer:

It has again been brought home to me quite clearly that we shouldn't think of God as the stopgap [Lückenbüßer] for the incompleteness of our knowledge...We should find God in what we know, not in what we don't know; God wants to be grasped by us not in unsolved questions about death, suffering, and guilt... We must recognize God not only where we reach the limits of our possibilities. God wants to be recognized in the midst of our lives, in life and not only in dying, in health and strength and not only in suffering, and action and not only in sin. The ground for this lies in the revelation of God in Jesus Christ. God is the center of life and doesn't just "turn up" when we have unsolved problems to be solved. (2010, 406-7).

Despite the fundamental significance of what Bonhoeffer is affirming, an awareness of the limits of science can serve an important apologetic purpose. The reason for this is that contemporary Western Christianity finds itself in a defensive position within a culture that has been shaped by naturalistic assumptions. This means that apologetics can serve an important role in challenging the presumptiveness of this culture. At the same time, apologetics must be recognized for what it is: a way to help some people become more open to the possibility that God exists. Christianity, however, is not grounded in the creature's imagining that a god may exist; it is grounded in God's self-revelation. According to the non-generic theology of Christianity, it is the triune God who tells the world that there is a God who creates, orders, and provides. This God discloses himself freely, by way of a special divine action that is not confined to the origin of creation or to the regulative sustaining of the universe by way of natural laws. Indeed, the fulfilment of God's self- 
revelation occurs when God establishes union with creation in Jesus Christ, thereby breaking the despair of the natural world's 'inclosing reserve' (Kierkegaard 1980, 63).

\section{B. THE GOD BEHIND NATURALISTIC EVOLUTION}

A further conversation in which Christians find themselves caught up in negotiations between naturalism and theism is the conversation about evolution and God. It is in this conversation, perhaps more than any other, that Christians can find themselves drawn towards a deistic vision of God - towards a theology that views God as creating a universe that he then leaves largely to itself. Why does this happen? Even if a Christian is happy to accept a non-literal reading of the Bible, the theory of evolution still presents Christians with a number of challenges that are difficult to negotiate. For example:

(1) Genetic variation appears to be the result of mutations that are somewhat random, i.e., have 'no purpose in mind' (Dawkins 1986, 5). ${ }^{31}$ That is, it is hard to see consistent purpose in these mutations, given that so many mutations bring about death and suffering in creation. $^{32}$

(2) The natural world appears to be characterized by the regularity of the stronger outsurviving the weaker. For John Haught, this 'points to the underlying indifference of natural selection, the mechanism that so mercilessly eliminates the weaker organisms' $(2003,70)$.

(3) The process of evolution takes time. It is hard to imagine why an intelligent creator would take so much time, and put creation through so much suffering, to create the kind of creature that God has elected to reflect his image and share in covenant fellowship with him.

While evolution presupposes a certain amount of regularity, it is easy to see why these problems invite the view that evolution is characterized by a randomness that challenges a Christian account of providence. Furthermore, when evolutionary theories are developed by MN, they are likely to assume a higher degree of randomness than empirical science itself is able to discern (because naturalistic theories rule out the possibility of a providential guide in a way that empirical science cannot). Moreover, naturalistic evolutionary theories are incompatible with a teleological or theological worldview that expects human beings (as the unique image bearers of God) to come into existence. According to naturalism, the emergence of human beings (or any other creature) is 
the result of particular genetic mutations occurring accidentally, by chance. Indeed, if we were to look more closely at what the emergence of human beings would require, human beings turn out to be an unfathomably unlikely outcome-moreover, for the naturalist, matter, stability (as we know it), and life in general are an unfathomably unlikely development (see Collins, 2005, 47$75)$.

As such, naturalistic theories of evolution are going to conflict with much of what Christianity has to say about God's providence and the place of human beings in the world. ${ }^{33}$ To be clear, this is not because of a tension between Christianity and evolutionary science per se but because of tensions between Christianity and naturalistic evolutionary theories which disavow the possibility that evolution might be planned, ordered, and/or guided. When the MNist assumes the randomness that naturalism entails, he does not do so for empirical reasons but because of naturalistic assumptions that have been incorporated into his methodology and which, as Patrick

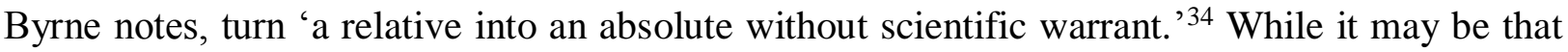
the emergence of human beings, or any other creature, can appear to be purely accidental, this does mean that it actually is.

In sum, the cultural acceptance of $\mathrm{MN}$ invites a perception of randomness that is difficult to align with Christianity. In the midst of this culture, it can be difficult for Christians to challenge the naturalistic assumption of (total) randomness without coming under fire from neo-Darwinians (who tend to associate such challenges with the Intelligent Design movement). To try to negotiate this territory, some Christians_-including Robert Russell, Nancey Murphy, George Ellis, John Haught, Kenneth Miller, and John Polkinghorne-have advanced a non-interventionist account of divine action, according to which God does not actively violate or suspend any natural laws (as they have been interpreted by scientific investigation). ${ }^{35}$ So, rather than simply questioning some of the naturalistic conclusions of contemporary science, they have developed theologies that, to some extent, allow for the randomness that naturalism entails. In these theologies, God keeps his distance from creation in a way that makes him 'functionally non-existent' (Slife and Reber 2009, 69). This position is often justified theologically by suggesting that, out of love, God distances himself from creation so as to give creation the space to define itself as other than God. ${ }^{36}$ John Haught, for example, writes: 'genuine love never forces or compels. Love allows others sufficient scope to become themselves. So if there is truth in the biblical conviction that God really cares for this world as something other than God, then the universe must always have had some degree of autonomy, even during its long prehuman evolution.' (2003, 70). On Haught's account, in order to give creation the freedom to be genuinely other, God must also allow creation to go astray. That is, God must allow creation to evolve in a way that comes to be characterized by natural evil: a 
form of evil that can appear somewhat random. Creation must have the "autonomy" to mutate in its own random ways. John Haught argues further:

... a coherent theology may argue that God could not truly care for the universe unless the universe is allowed in some sense to be self-actualizing, though selfactualizing in a way that occurs within the boundary of relevant possibilities proposed to it by its creator. The enormous epochs of gradual evolutionary emergence, and the autonomous evolution of life by random variation and natural selection, are consistent with the idea of a God who loves the world enough to allow it to become distinct from its creative ground. (2003, 70; cf. 168).

So, for Haught, the apparent randomness of evolution is not itself random but an inevitable consequence of God determining that creation should have an autonomy to develop in its own ways. This, he notes, on the basis of his naturalistic assumptions, is 'essential to evolution's recipe' $(2003,58-60){ }^{37}$

The reason for referring to Haught's noninterventionist position here is that it represents one of the common ways in which Christian thinkers have sought to reconcile naturalistic renderings of evolution with Christian theism. What is worth noting here is that the recent surge of noninterventionist theologies reflects a pressure to conform to suppositions that are clearly not as metaphysically neutral as is widely assumed. If this is the case, such theologies are indirectly utilising MN. That is, they endorse metaphysical assumptions that cannot only not be demonstrated by empirical science but are also in tension with Christianity. What becomes clear is that attempts to harmonize Christian theology with naturalistic science inevitably lead to deistic or Epicurean theologies in which God is more absent than the Biblical witness would seek to claim, or, indeed, than empirical science is able to demonstrate. No matter how culturally appealing a compromise, it is problematic for Christian theists to attempt to meet naturalism "halfway".

\section{(3) MN CAN PROMPT CHRISTIANS TO DISREGARD THE REALITY OF GOD OR DENY ITS PLACE IN INTELLECTUAL DISCOURSE.}

Since evolutionary science has been characterized by $\mathrm{MN}$, it is common for evolutionary theories to make naturalistic assertions which, as we have seen, are hard to align with Christian theism. Scholars such as Stephen Pinker, Pascal Boyer, and David Sloan Wilson, for example, assert that 
God can be reduced to a false belief that arose by way of a misstep in the evolution of human psychology. It is standard, moreover, for evolutionary theorists to assert that human beings are a random accident of natural history. Although evolution is not incompatible with Christianity per $s e$, it is true that some naturalistic theories of evolution inevitably obstruct the task of Christian theology, just as some Christian theologies can serve to obstruct progress in the natural sciences.

One way to avoid the possibility of naturalistic theories of evolution getting in the way of Christian theology would be for Christian theology to require its adherents to commit to a methodology that assumes that the theory of evolution is false. However, most Christians who believe in evolution will strongly object to this option. This is because, for them, some version of evolution is almost certainly true. Consequently, it would call into question the integrity of Christianity if it were to require its theologians to assume that evolution is false (even if this made little or no difference to the actual practice of Christian theology). Still further, it would compound the perception that science and Christianity are mutually incompatible.

There is an inconsistency in the fact that most (if not all) Christian advocates of $\mathrm{MN}$ are happy to adopt the assumption that God has nothing to do with the natural order (to avoid Intelligent Design) but would be unlikely to think that Christian theology should ever adopt a methodology that would require them to deny evolution (because some naturalistic theories of evolution can find themselves in tension with Christianity). This inconsistency points to a latent perception amongst some Christian scientists that God is more optional in our understanding of reality than the theory of evolution (at least, practically speaking). When we commit to $\mathrm{MN}$, we are subliminally conditioned into thinking that the pursuit of scientific understanding is compromised by acknowledging the reality of a God who is actively involved in the world. As such, "God" is not considered to be more than an object of Christian belief, an idea that occupies a place in philosophy of religion or religious studies, a source of false hope, a postulate that can provide a foundation for morality and value. Too easily MN generates the supposition that theology is an optional mythology. It does not concern any form of mind-independent reality.

From a Christian perspective, such an attitude towards God constitutes a de facto rejection of God because the Christian believes that her faith denotes or, to use Robert Nozick's term, "tracks" the reality of one who sustains every moment and movement of history, into every atom and, indeed, vacuum constitutive of creation. So, while the Christian may be aware that God is beyond the limits of creaturely understanding, this should not invite the assumption that "God" can be no more than a figment of our minds or a postulate defined by the limits of the immanent order. It does not prompt the Christian to become caught up in thought experiments in which reality is assessed according to the hypothesis that there is nothing beyond nature. Such reactions 
would invite an 'eclipse of grace': a focus on the natural order as something that is simply 'there for reason to see'-something that can be understood in and of itself, apart from God (Taylor, 2007 222). The Christian resists these moves because her faith is defined by the recognition that there is no logic to creation apart from the triune God.

Ever aware that she exists before God, the Christian sets her mind on things above, not upon earthly things (to the exclusion of things above) (Colossians 3:2). By seeking to order her life before God, the Christian can begin to see the proper place of earthly things: can come to see earthly things as created things. The patterns of her mind can become attuned to the dynamics of creation, and her life of scientific service can come to be perceived as a Christian vocation. To draw on Søren Kierkegaard, she can begin to understand herself as 'an apostle'-one who has a divinely given purpose. 'By this call,' he writes, she 'does not become more intelligent, [she] does not acquire more imagination, greater discernment, etc. - not at all but by the paradoxical fact is sent by God on a specific mission' $(1997,95)$. The 'paradox' here lies in the fact that, on the one hand, she knows that she cannot claim this vocation for herself, cannot master the movements that it requires her to make. She believes that this 'mission' is purposed and sustained by the grace of God. On the other hand, she seeks to develop her own sensitivity to the fact that God is with her, governing her, and directing her in her vocation. Even though the apostle cannot directly communicate this providence to others, she does not bracket out her recognition of this providence. As Kierkegaard notes, the apostle will not find that God astonishes her with more intelligence, more imagination, greater discernment etc. However, she will find that her prayerful life of response will come to be characterized by the conversion of her mind as God draws her to himself (see Webster 2015, 22).

More requires to be said here than the scope of this essay allows. What should be clear, however, is that the naturalistic pursuit of knowledge is not proper to the Christian life before God. If the Christian adopts naturalism, she will find herself outside her element, like a fish out of water. Such commitment requires her to disregard the revelation and illumination that helps her to see the fullness of creation. It requires her to reorient her mind towards natural ends, to earthly things, and play into the illusion that there is nothing more to reality than natural phenomena. Such playfulness risks inviting confusion into her life of discipleship, as a life that otherwise seeks to be 'patterned after the great miracle and mystery of the Incarnation, in which [the human being] finds its basis, limit, and final hope' (Hunsinger 1991, 223).

It is true that the academic world is becoming increasingly secular. However, when the Christian scholar finds herself unable to convince a secular scholar of the reality of God, she should not anxiously reduce reality to the phenomena that can be directly seen by both of them. 
She should not give in to the wisdom of the world that, for Paul, God has made foolish (1 Corinthians 1:20-25). She should embrace a cruciform boldness with which she does not fall into temptation, but, in times of anguish, prays with earnestness (Luke 22:40-44). Such are the practices that are constitutive of a Christian's vocation.

How else might we think about the problem here? When the Christian adopts MN in order to speak in a language that is more respectable to the secular populace, she learns a language that is not her own. When she commits herself to this language, she can lose herself in this language. Like any person who starts to learn another language, that language can begin to become a part of her. She can discover herself thinking in that language, dreaming in that language, speaking to others outside the secular populace in that language. And she can begin to take pride in doing so because it is with this language that she finds acceptance as a respected scholar. When this happens, she can come to frown upon and be frustrated by the Christian language. Unsettled by the "naiveté" of the Church community, bored by the "ramblings" of the Sunday preacher, she starts to find herself detached from the life of the Church - because the Church does not speak her language, and she has allowed herself to forget and become impatient with the language of the Church. For her, the problem with the Church is that, so often, it is made up of a hotchpotch of characters who, from a secular academic perspective, can seem uninteresting. What compounds this situation is the confusion that derives from striving to be bilingual in this way: to be both faithful and profane. 'No one can serve two masters; for a slave will either hate the one and love the other, or be devoted to the one and despise the other.' (Matthew 6:24 NRSV).

If a Christian assumes the language of naturalism, it is hard to see how this will not generate a process of subliminal transformation whereby her epistemic base becomes tacitly conditioned into developing a naturalist metaphysic. And, if she continues to bear the name "Christian", she will find herself struggling to demonstrate that her "Christianity" does not get in the way of the secular pursuit of knowledge - the pursuit of those thinkers whose endorsement she seeks. The likely result is that the "Christian" finds herself imprisoned within the immanent frame thereby reducing the Gospel to a message that is more fathomable by the secular mind - a message about value, meaning, purpose, wonder, etc.

\section{CONCLUSION}

Let me conclude with five points which seek to summarize the Christian's relationship to the natural sciences. 
(1) Unless God surprises the world, it is hard to imagine that the scientific world is going to make a discovery that will lead to consensus within the scientific community that an event of divine action has occurred.

(2) Christians should acknowledge that it is unlikely that divine action will ever be deemed an appropriate explanation within the natural sciences. We do not need to look to naturalism to find the reason for this. The reasons can be theological. The Christian scientist should hesitate to offer theological explanations in her understanding of the natural world unless she believes that her faith clearly requires her to do so, for example, if she is asked to explain the record of the resurrection or a process of conversion (events which, if Scripture has any credence at all, involve special divine action). If, moreover, she is ever required to offer a more theological explanation, she should qualify her position with the statement "I believe that this is the case" to make it clear that her faith has played a role in her scientific assessment.

(3) If, however, the Christian is to make this qualification, she should also try to be clear that God is not simply the object of her own subjective, personal belief. As a Christian, she is likely to believe that God reveals himself within the history of the natural world. That is, she is likely to believe that she has been given to know God through the work of the Holy Spirit, and through the apostolic witness to Jesus Christ. And this has happened within the life of the Church, as it is shaped by the practices of prayer, the Eucharist, the witness of its members, and the history of discernment to which this faith gives rise. As such, she can add the further qualification that, for her, a scientific hermeneutic that does not allow for this recognition is insufficient for developing a complete understanding of the behaviour, structure, and history of the natural order or, more precisely, the contingent order.

(4) The Christian should be aware that $\mathrm{MN}$ is only appropriate for the person who is a naturalist. ${ }^{39}$ As we have seen, the assumptions of $\mathrm{MN}$ and the associated criteria are not metaphysically neutral. As such, the person who commits to $\mathrm{MN}$ assumes that naturalism is the most appropriate system of understanding for shaping scientific method. As we have seen, it is not at all clear why a person would make this assumption unless she were committed to naturalism. By taking up MN, the scientific world commits itself, therefore, to assumptions that are no less beyond the scope of scientific enquiry than the existence of God. Consequently, if scientists really are devoted to better understanding the nature of reality a posteriori, it is ironical that they should so confidently exclude $a$ priori a way of understanding the natural world that has the level of explanatory power possessed by theism. (This is especially the case since, as Quentin Smith notes, '[i]f naturalism is true, then [the naturalist's] belief in naturalism is accidentally true' (2001).) By shackling itself to naturalism, science makes the possibility that God exists and makes himself known to human 
beings becomes a threat to the entire scientific enterprise. For this reason, the Christian scientist has a duty not only to God but to science itself to discourage a commitment to MN.

(5) At the very least, the Christian scientist should encourage the secular world to practice science in a way that is less constraining. Again, something like methodological agnosticism might be appropriate here for the secular world. According to this method, the scientist acknowledges that her study of the natural world does not allow her to make theological or atheological assumptions. Again, the Christian can demonstrate that the person who wants to argue consistently that there is no room for theistic assumptions in the methodology of the natural sciences, should also argue that there is no room for naturalistic or atheistic assumption either. This would make it more difficult for science to develop in a way that oversteps its boundaries and generate theories on the basis of a priori premises that are incompatible with theism and thus the Christian faith.

So, what should we say about the Christian's approach to the sciences? While the Christian might encourage the secular scientist to adopt a methodology that is more neutral with respect to theology, the Christian herself should not embrace such a methodology. The reason for this is that the Christian believes that truth-claims definitive of the Christian faith are objectively true - that God exists and is personally present to human creatures. Intellectual and academic integrity requires, therefore, that she adopt a methodology that is compatible with her Christian understanding. By so doing, she can take up her scientific work as a Christian vocation; she can practice what she preaches - albeit in a way that recognises the hiddenness of God in the natural order. The finer details of what such a Christian approach to the sciences might look like would require its own discussion. ${ }^{40}$ However, whatever we might say about this approach, it must not be systematized by naturalism.

How then might we describe the scientist who is a Christian? Let us call her a witness. By faith, she has been given eyes to discern what naturalistic science cannot discern-whose reference is beyond the scope and immediate perception of science. She has been given to see that the universe is created and ordered by the triune God who acts and reveals himself in history. Accordingly, she has been given to speak prophetically about the nature of reality (both created and eternal) in ways that are not possible to the person who reduces reality to natural phenomena. By so doing, she not only speaks of amorphous spiritual truths but of the one "Truth" who undergirds every facet of creation: the God who creates the universe to be a proclamation of his handiwork, a declaration of his glory, and a voice of witness that cannot be silenced. ${ }^{41}$

The Christian, moreover, speaks of a kingdom that has dawned and resides among us, albeit in a way that goes unnoticed by academic pursuits who objective is restricted to the 
contingent rationality of a contingent order. With theological humility, the Christian acknowledges that God is not a part of that which is contingently rational and so she will recognise that her capacity to speak faithfully penetrates beyond the range of her unaided scientific voice. However, she also realizes that the two are inseparable from one another because she is a creature whose language will always be bound to the contingently rational. As such, she recognizes that being attuned to the sciences serves a critical role in enabling her, first, to communicate with those engaged at that level. But, second, she also recognises that the science can serve a role in testing that deliverances of her faith - in making sure that she is not misguided and making false claims about the nature and history of the world. Still further, her scientific voice is inseparable from her faithful voice because she is committed to the pursuit of truth - truth that includes the nature and purposes of the creator as well as the nature and purposiveness of the created.

When the scientific world tells the Christian scientist that science is incompatible with the language of faith, because science is essentially naturalistic, she must deny this. Consequently, she must deny the adoption of $\mathrm{MN}$, lest she allow herself to become caught up in a culture that seeks to silence her discourse and blind her to what she has been given to recognise. By resisting this culture, her scientific study can track the regularities of creation, trusting that her study is characterized by a reason, a logic, and pursuit of objective reality that is possible alone in a universe that has been created good through the loving purposefulness of the triune God. ${ }^{42}$

\section{NOTES}

${ }^{1}$ T.H. Leahey states that 'naturalism is science's central dogma' $(1991,379)$.

${ }^{2}$ It needs to be acknowledged that there are some scholars who equate MN with scientific enquiry (e.g. Southgate 2011). Under these circumstances, to say that scientific enquiry is MNist would be a tautology. Clearly, I do not want to argue against a Christian practicing scientific enquiry. So, if this were how MN were normally defined, I would not have a problem with MN (and there would be no point to this article). The problem, however, as I discuss later in the article, is that 'naturalism' is not consistently defined in this way. Also, naturalism is hardly ever employed as a metaphysically neutral position. It does not simply focus attention on physical processes and properties, but usually excludes the possibility of invoking a transcendent agent to explain the nature of reality - thereby reducing reality to the empirically analysable natural order. So, at the very least, MN should be seen to be a term that, in the modern world, is readily going to invite confusion. Further, it should not be all that surprising to find that MN is continuously seen to be a methodology that assumes, for the purposes of method (rather than tout court), that the natural world is all that exists.

As Alan Padgett points out, '[it] is just too easy to think of methodological naturalism as simply acting as if naturalism (full blown) were true: a highly dubious way of describing the practical objectivity of the natural sciences.' $(2012,96)$. For this reason, Padgett recommends that we stop using this term. I agree that this is the best way forward. It is hard to understand why MN should have the name that it does if it has nothing to do with the systematic approach of naturalism. (On this point, I imagine that many of those who endorse MN would think it would be unhelpful to start referring to scientific methodology as methodological scientism, because of its connotations-even if there were a way to define methodological scientism in a way that simply referred to the study of science.)

${ }^{3}$ Unfortunately, in the modern world, the term "natural" is not as neutral as it once was - in the days when scientists were known as natural philosophers. Today, naturalism tends to be viewed as a position that, at the very least, inspires forgetfulness of God. So, for example, were a person to self-identify as someone who is committed to naturalism, many people would be likely to assume that that person was committed to a set of suppositions that are incompatible with theism. 
${ }^{4}$ My understanding of MN here aligns with the following definitions. (1) James K. A. Smith affirms that MN 'claims
that science qua science must operate as if the universe were a closed system.' (2008, 880). (2) Del Ratzsch offers a
definition MN as the methodology that 'restricts its methods, presuppositions, conceptual resources, and results
wholly to the realm of nature and must proceed as if philosophical naturalism were true.' (2009, 58). (3) Murray Rae
defines it as the approach that 'holds that while God may exist and may be involved in the world, neither the empirical
sciences nor the standard methods of historical inquiry can appeal to divine agency as an explanatory category in
describing what happens in the world.' (2016, 98). (4) For Brad Gregory, it is 'the methodological postulate of
metaphysical naturalism, which entails that for science to be science, by definition it can pursue, identify, and
entertain only natural causes as plausible explanations of natural phenomena, with the universe as a whole regarded entertain only natural causes as plausible explanations of nat
as if it were a closed system of natural causes.' $(2008,505)$.

I am happy to recognise that these definitions can be disputed. However, they are also common enough (especially outside the field of science and religion) to make them viable ways of defining how MN has come to be understood.

${ }^{5}$ A person does not commit to a methodology that discounts certain explanations unless she thinks that it is possible for such explanations to get in the way of her particular practice. If, for example, a person said that a scientist should commit to methodological vegetarianism, this would come with the suggestion that eating meat could somehow potentially get in the way of scientific practice.

${ }^{6}$ I acknowledge that this essay is targeted at those who think Christianity requires some recognition of the fact that there are occurrences that take place within the natural order that require to be explained with recourse to special divine action. For those who do not think that this is the case, my argument will lose some of its force.

${ }^{7}$ There is strong biblical precedent for Christians to believe that conversion and continued faithfulness is enabled by God's activity and, in particular, the work of the Holy Spirit. See, for example: Matthew 16:15-17; John 16: 7-14; Acts 2:38, 5:32; Romans 8:5-16; Galatians 2:20, 4:6; Ephesians 2:4-8, 3:16-17 NRSV.

${ }^{8}$ Here, we could take "haphazard references to special divine action" to mean unbiblical references to an occasional divine action that would be more specific than references to the general providence with which God upholds the regularities of the natural order.

${ }^{9}$ This quote, attributed to Einstein, is engraved on the bench of the Einstein memorial.

${ }^{14}$ Paul de Vries was the first person to use the term MN in the conversation about science and religion. He cautiously defined it as the 'scientific method [that] requires that one explain data by appealing to natural laws and natural processes.' $(1986,70)$.

${ }^{15}$ Emphasis mine.

${ }^{17}$ Applegate risks being anachronistic in her discussion of "MN" because she suggests that "MN" is adopted before the term was first formally used. (See Numbers, 2003, 320 n. 2).

${ }^{18}$ For Applegate, 'backed by an understanding of the doctrine of creation', MN 'is for the Christian a theologically motivated practice' $(2013,37)$.

${ }^{19}$ This could be because Applegate is operating with a Christian version of naturalism - which seems to be the case later in her article. However, this is not entirely clear. Earlier in her article, she seems to suggest that the Christian scientist can operate with two methodologies-MN and a theological method- that are separate from one another but which can also inform one another from their mutually exclusive domains.

${ }^{20}$ To be clear, there is nothing inherently naturalistic about science. It is true that there are limits to the empirical sciences. It is also true that a scientist should be aware of these limits. However, an awareness of these limits should not require the scientist to commit to disregarding possibly significant factors beyond these limits, as is the case with MN.

${ }^{21}$ Alan Padgett also makes this point (2003, 82-83).

${ }^{22}$ On a related note, Plantinga and Huston Smith successfully challenged the naturalistic description of evolution as 'unsupervised' and 'unguided', which could be found in the official description of evolution produced by the National Association of Biology Teachers. Such a description of evolution would be a valid conclusion of a scientific investigation that is characterised by MN. However, it is not a conclusion that can be drawn by empirical investigation. Rather, it is based on the metaphysical assumptions that shape MN (see Witham 2002, 71-72).

${ }^{23}$ David Leech and Aku Visala make a similar case to Plantinga when they argue that scientific disciplines should be worldview neutral, insofar as they should not impose on the belief "God exists" or "God does not exist". Like Plantinga, they make their case with a particular example in mind: the account of Pascal Boyer who asserts that '[r]eligious notions are products of the supernatural imagination.' Boyer's conclusion, like Stark's conclusion, would be entirely appropriate for the person who is committed to MN (Leech and Visala 2011, 50; Boyer 2003, 119).

${ }^{24}$ If a concern for survival in the academy compromises the Christian's pursuit of truth, the Christian reverts to the patterns that evolution expects of her. There is something predictable about the practice of naturalism encouraging such reversion. See Plantinga's 'Evolutionary Argument Against Naturalism' (Plantinga 2011, 307-50).

${ }^{25}$ On a related note, Kenneth Oakes writes: 'Methodologies are notoriously prone to becoming metaphysics, and so a great deal of theology's native language and concepts - providence, revelation, divine commissioning, the Spirit's work of sanctifying historical and creaturely media - would be required to prevent viewing the NT as ultimately a failed attempt at history, rather than the viva vox Christi for the Church, and then viewing our own reconstructions as historically superior to or more enlightening the Scripture itself' $(2015,572)$. 
${ }^{26}$ To be clear, this is not to suggest that the universal discovery of the existence of God would necessarily change a single aspect of what we have discovered through science. I am also happy to acknowledge that, on the surface, this discovery would be unlikely to change the general practice of science (unless, of course, the universally recognised God started to become more active in the natural world in unpredictable ways). At the same time, I do not think that scientists would continue to endorse MN, unless it was redefined as a methodology that allowed for the possibility of supernatural explanations.

${ }^{27}$ Strictly speaking, if God is a necessary being, "nothing" is not logically possible. So the more accurate formulation would be "something other than God."

${ }^{28}$ As such, I agree with C. Stephen Evans when he acknowledges (with respect to MN in historical Jesus studies) that there is 'nothing objectionable, and possibly a good deal to be gained, when believing Christians who are historical biblical scholars seek to show what kind of knowledge about Jesus can be achieved, even when one is limited to evidence that would be admissible to a naturalist' $(1999,200)$.

${ }^{29}$ It would be hard to demonstrate this tendency without providing a detailed survey of the literature in the field of science and Christianity, and this would take us beyond the scope of this essay. However, a read through the excellent volume, The Blackwell Companion to Science and Christianity, does reveal a slight tendency towards a more generic theology - although this volume clearly does engage more specifically with Christianity. One of the reasons that theology tends to be more generic in the conversation about science and Christianity is because the discussion about science and Christianity often merges with the conversation about science and religion (where it is appropriate to talk about God generically). What we often find is that Christians will try to demonstrate that science and Christianity are compatible by simply showing that science and theism are compatible.

My concern here is that some Christians can end up advocating a more generic or apophatic theology in order to avoid making claims that would be offensive to naturalistic science. For example, in the conversation about science and Christianity, Christians will rarely refer to events such as the incarnation, resurrection, and Pentecost, because such events tend are characterised by special divine action, which would violate or suspend the regularities observed by naturalistic science. Without getting into these debates, I would suggest that Christians should resist the temptation to compromise or dilute their presentation of Christianity in order to show that Christianity is compatible with naturalistic science. Indeed, Christian scientists should be willing to allow their Christian convictions to call into question certain naturalistic conclusions (that are essentially incompatible with the more specific beliefs of Christianity).

To encourage more engagement between science and Christianity, the conversation about science and Christianity would benefit from being more engaged with the history of Christian reflection on Scripture, Christology, Trinitarian theology, providence etc. That is, rather than allowing the field of science and Christianity to be centred around a God who is beyond the sphere of the natural sciences (and who, perhaps, always conforms to the regularities observed by the natural sciences), it could seek to become more informed by the history of the Church's reflection on the triune God's acts of self-revelation.

${ }^{30}$ This dynamic reflects Norman Wirzba astute observation: 'Theoria is never far removed from an ethos, and that means our looking is invariably in service of or in response to particular concerns, anxieties, ambitions or desires, i.e., every theoria recommends and grows out of an askesis or way of being in the world' $(2016,216)$.

${ }^{31}$ Francisco Ayala writes: '[t]he overall process of evolution cannot be said to be teleological in the sense of proceeding towards certain specified goals, preconceived or not' $(1998,42)$.

${ }^{32}$ Simon Conway Morris challenges this position by arguing (contentiously but forcefully) that purpose can be discovered scientifically (2003).

${ }^{33}$ Notably, not all Christian thinkers think that evolution is guided or that human beings are an inevitable outcome. For example, Kenneth Miller writes: 'Yet, curiously, that is exactly what many expect of a religious person engaged in the study of natural history - they want to know how God could have ensured the success of mammals, the rise of flowering plants, and most especially, the ascent of man. My answer, in every case, is that God need not have. Evolution is not rigged, and religious belief does not require one to postulate a God who fixes the game, bribes the referees, or tricks natural selection. The reality of natural history, like the reality of human history, is more interesting and more exciting' (1999, 238).

${ }^{34}$ Prior to this, he writes, drawing on Karl Popper, 'it is impossible to establish by empirical means alone that a given series of events is absolutely random and conforms to no conceivable intelligible pattern. The most that can be established is that the data are random relative to some specifiable (albeit extremely complex) kinds of patterns. To claim that some series of events is absolutely random goes beyond scientific verifiability' (2006, 658; see also Popper 1959, 189-205).

${ }^{35}$ For example, Russell, Murphy, Ellis, and Miller argue that God limits his activity to the quantum level, where quantum indeterminacy would allow God to act without breaking any natural laws (see Edwards 2006, 816-33, and Russell 2006, 579-95).

${ }^{36}$ The utility of this position is seen to be twofold: (1) it provides an account of God that is more compatible with naturalistic theories of evolution; and (2) it provides a defense against the problem of natural evil and chaos-it extends the free will defense to the whole of creation by proposing that it is the natural world that is "responsible" for 
natural evil and chaos. For a deeper discussion of some of the key issues here, I recommend Michael Murray's Nature Red in Tooth and Claw.

${ }^{37}$ For further critical engagement with Haught and others on this issue (and on the quoted passages), I highly recommend Michael Murray's chapter, 'Chaos, Order, and Evolution' $(2008,166-92)$.

${ }^{39}$ However, insofar as naturalism is a metaphysical position, there is an inconsistency in even the naturalist committing to naturalism (methodological or metaphysical) (see Rea 2002, 59).

${ }^{40}$ As Michael Rea notes, '[it is notoriously] hard to say exactly what methods are supposed to count as the methods of science.' $(2002,67)$.

${ }^{41}$ See Psalms 8, 19:1, 66:4, 148; Luke 19:40 NRSV.

${ }^{42}$ I am very grateful to Michael Rea, Denis Alexander, Ruth Bancewicz, Alan Torrance, Oliver Crisp, N.T. Wright, and the anonymous reviewers for helpful feedback on an earlier version of this article. Further, I greatly benefited from conversations with Malcolm Jeeves, Wilson Poon, John Wyatt, Jennifer Wiseman, Michael Burdett, David Congdon, and C. Stephen Evans, who helped guide my thinking on this topic.

Finally, I want to thank the John Templeton Foundation for funding the Scientists in Congregations, Scotland programme, which gave me the opportunity to work on this paper in continual conversation with scientists across Scotland. I should add that the views expressed in this essay are of the author and should not be attributed either to the John Templeton Foundation or to the aforementioned conversation partners.

\section{REFERENCES}

Alexander, Denis. 2008. Creation or Evolution: Do We Have to Choose?. Grand Rapids, MI: Monarch Books.

Applegate, Kathryn. 2013. 'A Defense of Methodological Naturalism.’ Perspectives on Science and Christian Faith 65:37-45.

Ayala, Francisco. 1998. 'Teleological Explanation in Evolutionary Biology.' In Nature's Purposes: Analyses of Function and Design in Biology. ed. Colin Allen, Marc Bekoff, and George Lauder. Cambridge, MA: MIT Press.

Bonhoeffer, Dietrich. 2010. Letters and Papers from Prison (Dietrich Bonhoeffer Works, vol. 8). ed. Christian Gremmels, Eberhard Bethge, Renate Bethge, and Ilse Tödt, English edn. ed. John W. de Gruchy and trans. Isabel Best, Lisa Dahill, Reinhard Krauss, and Nancy Lukens. Minneapolis, MN: Fortress Press.

Boyer, Pascal. 2003. 'Religious Thought and Behavior as By-Products of Brain Function.’'Trends in Cognitive Sciences 7:119-24.

Byrne, Patrick. 2006. 'Quaestio Disputata - Evolution, Randomness, and Divine Purpose: A Reply to Cardinal Schönborn.' Theological Studies 67:653-65.

Collins, Robin. 2005. 'A Scientific Argument for the Existence of God.' In Reason for the Hope Within, ed. Michael Murray, 47-75. Grand Rapids, MI: Eerdmans.

Conway Morris, Simon. 2003. Life's Solution: Inevitable Humans in a Lonely Universe. Cambridge: Cambridge University Press.

Cunningham, Conor. 2010. Darwin's Pious Idea: Why the Ultra-Darwinists and Creationists Both Get It Wrong. Grand Rapids, MI: Eerdmans. 
Dawes, Gregory. 2011. 'In Defense of Naturalism.' International Journal for Philosophy of Religion 70:3-25.

Dawkins, Richard. 1986. The Blind Watchmaker. New York, NY: Norton.

—. 2006. The God Delusion. Boston, MA: Houghton Mifflin.

De Vries, Paul. 1986. 'Naturalism in the Natural Sciences.' Christian Scholars Reviews 15:38896.

Edwards, Denis. 2006. 'Resurrection and the Costs of Evolution: A Dialogue with Rahner on Noninterventionist Theology.' Theological Studies 67:816-33.

Evans, C. Stephen. 1999. 'Methodological Naturalism in Historical Biblical Scholarship.' In Jesus and the Restoration of Israel: A Critical Assessment of N.T. Wright's Jesus and the Victory of God, ed. Carey C. Newman, 180-205. Downers Grove, IL: Intervarsity Press.

Gregory, Brad S. 2008. 'No Room for God? History, Science, Metaphysics, and the Study of Religion.' History and Theory 47: 495-519.

Hare, John. 2012. 'Evolutionary Theory and Theological Ethics.' Studies in Christian Ethics 25:244-54.

Harrison, Peter. 2010. 'Introduction.' In The Cambridge Companion to Science and Religion, ed. Peter Harrison, 1-18. Cambridge: Cambridge University Press.

Haught, John. 2003. Deeper than Darwin: The Prospect of Religion in the Age of Evolution. Boulder, CO: Westview.

Hunsinger, George. 1991. How to Read Karl Barth: The Shape of His Theology. New York: Oxford University Press.

Kierkegaard, Søren. 1980. The Sickness unto Death: A Christian Psychological Exposition for Upbuilding and Awakening. ed. and trans. Howard V. and Edna H. Hong (Princeton, NJ: Princeton University Press.

—'The Difference between a Genius and an Apostle'. 1997. In Without Authority, trans. Howard and Edna Hong. Princeton, NJ: Princeton University Press.

Koperski, Jeffrey. 2008. 'Two Bad Ways to Attack Intelligent Design and Two Good Ones.' Zygon: Journal of Religion and Science 43:433-49.

Leahey, T.H. 1991. A History of Modern Psychology. Englewood Cliffs, NJ: Prentice Hall.

Leech, David, and Aku Visala. 2011. 'The Cognitive Science of Religion: Implications for Theism?.' Zygon: Journal of Religion and Science 46:47-64.

McLeish, Tom. 2014. Faith and Wisdom in Science. Oxford: Oxford University Press.

McMullin, Ernan. 1982. 'Values in Science.' PSA: Proceedings of the Biennial Meeting of the Philosophy of Science Association 2:2-28. 
Miller, Kenneth. 1999. Finding Darwin's God. New York, NY: HarperPerennial.

Monton, Bradley. 2009. Seeking God in Science: An Atheist Defends Intelligent Design. Toronto, Ont: Broadview Press.

Murphy, Nancey. 1993. 'Phillip Johnson on Trial.' Perspectives on Science and Christian Faith 45:26-36.

Murray, Michael (ed.). 2008. Nature Red in Tooth and Claw: Theism and the Problem of Animal Suffering. Oxford: Oxford University Press.

Mytyk, Chelsea Rose, and Harry Lee Poe. 2008 'From Scientific Method to Methodological Naturalism: The Evolution of an Idea.' Perspectives on Science and Christian Faith 59:213-18.

Numbers, Ronald L.. 2003. 'Science without God: Natural Laws and Christian Beliefs.' In When Science and Christianity Meet, ed. David C. Lindberg, Ronald L. Numbers, 265-285. Chicago: University of Chicago Press.

Oakes, Kenneth. 2015. 'Normative Protestant Christology.' In The Oxford Handbook of Christology, ed. Francesca Aran Murphy, 568-81. Oxford: Oxford University Press.

O’Connor, Robert. 1997. 'Science on Trial: Exploring the Rationality of Methodological Naturalism.' Perspectives on Science and Christian Faith 49:15-30.

Osborn, Ronald. 2014. Death Before the Fall: Biblical Literalism and the Problem of Animal Suffering. Downers Grove, IL: IVP Academic.

Padgett, Alan. 2003. Science and the Study of God: A Mutuality Model for Theology and Science. Grand Rapids, MI: Eerdmans.

Padgett, Alan. 2012. 'Practical Objectivity: Keeping Natural Science Neutral.' In The Blackwell Companion to Science and Christianity, ed. J.B. Stump and Alan Padgett, 93-102. Malden, MA: Wiley-Blackwell.

Pennock, R.T.. 1999. Tower of Babel: The Evidence Against the New Creationism. Cambridge, MA: MIT Press.

Plantinga, Alvin. 1996. 'Methodological Naturalism?.' In Facets of Faith and Science, ed. J. van der Meer, 177-222. Lanham, MA: University Press of America.

-2009. 'Games Scientists Play.' In The Believing Primate: Scientific, Philosophical, and Theological Reflections on the Origin of Religion. ed. Jeffrey Schloss and Michael Murray, 139-65. Oxford: Oxford University Press.

-2011. Where the Conflict Really Lies: Science, Religion, and Naturalism. New York, NY: Oxford University Press.

Popper, Karl. 1959. The Logic of Scientific Discovery. New York, NY: Harper \& Row, 189-205. 
Rae, Murray. 2016. 'Theological Interpretation and Historical Criticism.' In A Manifesto for Theological Interpretation, ed. Craig G. Bartholomew and Heath A. Thomas. 94-109. Grand Rapids, MI: Baker Academic.

Ratzsch, Del. 2009. 'Science and Religion.' In The Oxford Handbook of Philosophical Theology, ed. Thomas P. Flint and Michael C. Rea. 54-77. Oxford: Oxford University Press.

Rea, Michael. 2002. World Without Design: The Ontological Consequences of Naturalism Oxford: Oxford University Press.

Reber, Jeffrey, and Brent Slife. 2009. 'Is there a Pervasive Implicit Bias Against Theism in Psychology.' Journal of Theoretical and Philosophical Psychology 29:63-79.

Russell, Robert John. 2006. 'Quantum Physics and the Theology of Non-Interventionist Objective Divine Action.' In The Oxford Handbook of Religion and Science, ed. Philip Clayton and Zachary Simpson, 579-95. Oxford: Oxford University Press.

Smith, James K.A. 2008. 'Is the Universe Open for Surprise? Pentecostal Ontology and the Spirit of Naturalism?' Zygon 43:879-96.

Smith, Quentin. 2001. 'The Metaphilosophy of Naturalism.' Philo: A Journal of Philosophy 4:195-215.

Southgate, Christopher. 2011. 'The Contemporary Conversation - an uneasy truce?.' In God, Humanity and the Cosmos - 3rd Edition: A Textbook in Science and Religion, ed. Christopher Southgate. 29-30. London, UK: T\&T Clark.

Stump, J.B. and Alan Padgett. 2012. The Blackwell Companion to Science and Christianity. Malden, MA: Wiley-Blackwell.

Taylor Charles. 2007. A Secular Age. Cambridge, MA: The Belknap Press of Harvard University Press.

Torrance, T.F.. 1998. Divine and Contingent Order. Edinburgh: T\&T Clark.

Webster, John. 2015. 'What Makes Theology Theological?' Journal of Analytic Theology 3:1728.

Wirzba, Norman. 2016. 'Christian Theoria Physike: On Learning to See Creation.' Modern Theology 32:211-30.

Witham, Larry. 2002. Where Darwin Meets the Bible: Creationists and Evolutionists in America. Oxford: Oxford University Press. 